\title{
Analyzing interdependencies between policy mixes and technological innovation systems: The case of offshore wind in Germany
}

\author{
Kristin Reichardt ${ }^{\text {a,b }}$, Simona O. Negro ${ }^{\text {b,* }}$, Karoline S. Rogge ${ }^{\text {a,c }}$, Marko P. Hekkert ${ }^{\text {b }}$ \\ a Fraunhofer Institute for Systems and Innovation Research ISI, Breslauer Str. 48, 76131 Karlsruhe, Germany \\ b Utrecht University, Heidelberglaan 2, 3584 CS Utrecht, The Netherlands \\ c SPRU, Science and Technology Policy Research, Jubilee Building, University of Sussex, Brighton BN1 9SL, UK
}

\section{A R T I C L E I N F O}

\section{Article history:}

Received 8 November 2014

Accepted 29 January 2016

Available online 23 February 2016

\section{Keywords:}

Technological innovation system

Policy mix

Evolution

Interdependencies

Offshore wind

\begin{abstract}
A B S T R A C T
One key approach for studying emerging technologies in the field of sustainability transitions is that of technological innovation systems (TIS). While most TIS studies aim at deriving policy recommendations - typically by identifying system barriers - the actual role of these proposed policies in the TIS is rarely looked at. In addition, often single policy instruments instead of more encompassing policy mixes are considered. We address these shortcomings by applying a more comprehensive policy mix concept within the TIS approach. In doing so we analyze interdependencies between the policy mix and the TIS by shedding light on the role of the policy mix for TIS functioning and performance as well as how TIS developments influence the evolution of the policy mix. We explore these interdependencies for the case of offshore wind in Germany, using data from event history analysis and expert interviews. We find highly dynamic interdependencies with reoccurring patterns of systemic problems and adjustments of the policy mix, which are fuelled by high policy mix credibility and supportive actors. Our study constitutes a first step incorporating the policy mix concept into the TIS approach, thereby enabling a better understanding of real dynamics occurring in TIS.
\end{abstract}

(c) 2016 Elsevier Inc. All rights reserved.

\section{Introduction}

In order to prevent the costly consequences of climate change, a decarbonization of the energy system is needed. This transition requires the development and diffusion of low-carbon energy technologies, such as technologies based on renewable energies. However, without policy intervention these technologies will not be developed and will not diffuse at a rate and scale required for such a radical transition. A major reason for this is multiple failures in place, which require not just single policy instruments but rather a policy mix to address them (Lehmann, 2010; Weber and Rohracher, 2012). Besides comprising several interacting policy instruments, such policy mixes more recently have been highlighted to also include a policy strategy, policy processes and overarching policy mix characteristics (Flanagan et al., 2011; Rogge and Reichardt, 2013).

Abbreviations: BMVBS, Federal Transport Ministry; BMU, Federal Environment Ministry; BMWi, Federal Economics Ministry; BNetzA, Federal Network Agency; BSH, Federal Maritime and Hydrographic Agency; EEG, Renewable Energy Act; EEZ, Exclusive Economic Zone; EFL, Energy Feed-in Law; EnWG, Energy Economy Law; FIT, feed-in tariff; In.dp, demand pull instrument; In.sys, systemic policy instrument; In.tp, technology push instrument; OW, offshore wind; P.impl, policy implementation; PM, policy mix; P.mak, policy making; PS, policy strategy; RET, renewable energy technologies; TIS, technological innovation system; TSO, transmission system operator.

* Corresponding author.

E-mail address: s.o.negro@uu.nl (S.O. Negro).
Emerging technologies, such as renewable energy technologies, are not only influenced by a policy mix but actually are impacted and shaped by an entire system, a so-called technological innovation system (TIS). Scholars on technological innovation systems study the evolution of such technologies as the outcome of complex interaction processes between actors, institutions (hard and soft rules) and physical artifacts (e.g. Negro et al., 2008; Suurs et al., 2010). This includes the analysis of the structure of the innovation system as well as its functioning (Bergek et al., 2008; Hekkert et al., 2007). In doing so, system failures or systemic problems are identified and, based on these, recommendations for specific policy interventions are derived.

While the literature on TIS has helped policy makers by developing the framework necessary for analyzing where policy intervention is needed and has offered a toolbox for such policy intervention (Bergek et al., 2008; Wieczorek and Hekkert, 2012), a more thorough understanding of the actual interlinkages between policies and the TIS they are embedded in, as well as a more differentiated treatment of policies are still largely lacking. There exist some TIS studies that analyze the role of policies to improve innovation system functioning, yet they are mostly limited to policy instruments. A recent example is Kivimaa and Virkamäki (2013), which analyzes the impact of several policy instruments on TIS functioning and in doing so detects design flaws in single policy instruments. Similarly, McDowall et al. (2013) explore how policy instruments influence system functioning, and addresses system weaknesses for the onshore wind innovation system in four countries. It concludes with lessons for 
a low-carbon instrument mix, e.g. the need to include systemic policy instruments alongside traditional demand pull and technology push. However, these studies do not consider features of a more encompassing policy mix, such as a policy strategy and policy processes.

In this article we incorporate a more comprehensive policy mix concept into the TIS approach by explicitly analyzing the role of a differentiated policy mix in the development of TIS. More specifically, we study the evolution of a technological innovation system and its corresponding policy mix and analyze interdependencies between the two. We thereby do not only examine the role of the policy mix for TIS functioning and performance but also investigate how particular TIS developments affect the coming about of the policy mix. By applying the policy mix concept within the TIS approach we enable a better understanding of the role of the policy mix in emerging innovation systems. Regarding the policy mix we rely on a recently proposed concept, which defines a policy mix as consisting of the four building blocks elements, processes, dimensions and characteristics (Rogge and Reichardt, 2013; see Section 2.2). We consider all of these building blocks, i.e. the policy strategy and the instrument mix as elements, policy making and implementation as policy processes, actors as an important policy mix dimension and the influential policy mix characteristic credibility.

We explore our research question of the interdependencies between the policy mix and TIS developments for the case of offshore wind in Germany, which we chose for the following reasons. First, the policy mix promoting the development and diffusion of this technology appears particularly rich and dynamic, comprising a policy strategy and an encompassing instrument mix, which have been adjusted several times. Second, offshore wind is an emerging renewable energy technology with great technological potentials expected to play a key role in the transition of the German energy system (BMWi and BMU, 2010), but is faced with a number of difficulties. In combination, these factors make offshore wind in Germany an ideal candidate to study the role of the policy mix for the development of the TIS.

We proceed as follows: Section 2 reviews the literatures on TIS and on policy mixes and derives our analytical framework, which combines these two approaches. Section 3 introduces the research case of offshore wind in Germany. While Section 4 outlines our method for analyzing TIS and policy mix developments over time, Section 5 describes these developments for the German offshore wind TIS between 1993 and 2013. Based on this description, Section 6 discusses the interdependencies between the TIS and policy mix developments, and Section 7 concludes.

\section{Theoretical background}

\subsection{Technological innovation systems}

The recent years have seen a fast growing literature applying the technological innovation systems framework for studying sustainability transition processes such as the transformation of the energy system (Jacobsson and Bergek, 2011; Truffer et al., 2012). A technological innovation system (TIS) can be defined as the network of actors, rules and material artifacts that influence the speed and direction of technological change in a specific technological area (Hekkert et al., 2007; Markard and Truffer, 2008a). The purpose of analyzing a TIS is to evaluate the development of a particular technological field in terms of the structures and processes that support or hamper the development and diffusion of novel technologies. The ultimate aim is to derive implications for policy makers and other actors so as to remedy ills in the functioning of such systems (Bergek et al., 2008).

The structural analysis of systems comprises mapping of its elements - actors, networks, institutions, and infrastructure - and evaluating their capacity to stimulate innovation. These structural elements, their presence or absence as well as their capacities are critical to the functioning of innovation systems (Wieczorek and Hekkert, 2012).

While different innovation systems may have similar structural elements, they may function in an entirely different way. Therefore, measuring the functioning of innovation systems constitutes another crucial step of analysis. Table 1 presents a list of key processes that need to be fulfilled for a TIS to build up and function well (Hekkert et al., 2007). These key processes are called system functions.

Structure and functions complement each other. While functions are more evaluative in character and allow for assessing of what works well and what does not within the TIS, the structure is what needs to be adjusted to enable better system functioning and thus should be the target of policy intervention. Put differently, functions that are badly fulfilled indicate problems in the structure. By identifying where the problems are within the system, these problems can more easily be addressed by policy makers. For example, if function knowledge diffusion is weak then the cause could be related to a lack of networks in which knowledge is exchanged (Wieczorek et al., 2013). Such problems are usually called systemic problems or system failures and can be defined as "factors that negatively influence the direction and speed of innovation processes and hinder the development and functioning of innovation systems" (Wieczorek and Hekkert, 2012, p. 79). Finally, the structure and functioning of a TIS have a direct influence on its performance, i.e. the development, use and diffusion of the technology under study (Bergek et al., 2008; Tigabu et al., 2013).

\subsection{Policy mixes}

Although policies are part of the institutional structures that make up a TIS and play an important role in TIS analyses, only few studies have focused on policies and their impact on the rest of the TIS (Foxon et al., 2005; Kivimaa and Virkamäki, 2013). Even fewer studies have focused on studying TIS-related policies from a policy mix perspective. At the same time the need for considering such policy mixes - both for researchers and policy makers - has been increasingly stressed in the

Table 1

Description of seven key system functions of a TIS.

\begin{tabular}{|c|c|c|}
\hline $\begin{array}{l}\text { Function } \\
\text { number }\end{array}$ & Function name & Description \\
\hline F1 & $\begin{array}{l}\text { Experimentation and } \\
\text { production by } \\
\text { entrepreneurs }\end{array}$ & $\begin{array}{l}\text { Entrepreneurs are essential for a } \\
\text { well-functioning innovation system. Their } \\
\text { role is to turn the potential of new } \\
\text { knowledge, networks, and markets into } \\
\text { concrete actions to generate - and take } \\
\text { advantage of - new business opportunities. }\end{array}$ \\
\hline $\mathrm{F} 2$ & Knowledge development & $\begin{array}{l}\text { Mechanisms of learning are at the heart of } \\
\text { any innovation process, where knowledge } \\
\text { is a fundamental resource. Therefore, } \\
\text { knowledge development is a crucial part of } \\
\text { innovation systems. }\end{array}$ \\
\hline F3 & Knowledge exchange & $\begin{array}{l}\text { The exchange of relevant knowledge } \\
\text { between actors in the system is essential to } \\
\text { foster learning-processes. }\end{array}$ \\
\hline F4 & Guidance of the search & $\begin{array}{l}\text { The processes that lead to a clear } \\
\text { development goal for the new technology } \\
\text { based on technological expectations, } \\
\text { articulated user demand and societal } \\
\text { discourse enable selection, which guides } \\
\text { the distribution of resources. }\end{array}$ \\
\hline F5 & Market formation & $\begin{array}{l}\text { This function refers to the creation of a } \\
\text { market for the new technology. In early } \\
\text { phases of developments this can be a small } \\
\text { niche market but later on a larger market is } \\
\text { required to facilitate cost reductions and } \\
\text { incentives for entrepreneurs to move in. }\end{array}$ \\
\hline F6 & Resource mobilization & $\begin{array}{l}\text { The financial, human and physical resources } \\
\text { are necessary basic inputs for all activities in } \\
\text { the innovation system. Without these } \\
\text { resources, other processes are hampered. }\end{array}$ \\
\hline F7 & Creation of legitimacy & $\begin{array}{l}\text { Innovation is by definition uncertain. A certain } \\
\text { level of legitimacy is required for actors to } \\
\text { commit to the new technology and execute } \\
\text { investments, take adoption decisions etc. }\end{array}$ \\
\hline
\end{tabular}

Source: adapted from Wieczorek et al. (2013). 
Table 2

Development of installed capacity of offshore wind.

\begin{tabular}{lllll}
\hline & & 2012 & 2020 & 2030 \\
\hline Installed capacity (in GW) & EU & 5.3 & 40 & 150 \\
& Germany & 0.28 & 6.5 & 15 \\
\hline
\end{tabular}

Source: Own compilation based on EWEA (2011a,b); CDU et al. (2013); EWEA (2014).

climate, energy and innovation policy literature (Matthes, 2010; Nauwelaers et al., 2009; see Rogge and Reichardt (2013) for a detailed overview). The main argument for this need is that the necessary transformation of socio-technical systems like the energy system is slowed down by multiple market, system and institutional failures in place requiring multi-faceted policy intervention (Weber and Rohracher, 2012). Therefore we are often dealing with complex policy mixes rather than single instruments (Braathen, 2007; Lehmann, 2010). The literature on policy mixes stresses the importance of such policy aspects as instrument design features (Kemp and Pontoglio, 2011), policy mix characteristics (Rogge and Reichardt, 2013), and policy processes (Flanagan et al., 2011). One strength of considering policy mixes in innovation system studies would be a more encompassing understanding of the role of 'policies' in the innovation system, which may ultimately enable a better understanding of these systems themselves. In this regard, applying a well-defined policy mix terminology that explicitly differentiates between policy instruments, a policy strategy, policy processes and overarching policy mix characteristics such as credibility is thought to increase the analytical clarity of empirical TIS studies (Rogge and Reichardt, 2013).

Despite these increasing calls for considering overarching policy mixes (Flanagan et al., 2011), policy mix definitions in the literature thus far have remained rather narrow and ambiguous. Addressing this problem Rogge and Reichardt (2013) propose a more comprehensive policy mix concept as tool for policy analyses, including elements, processes, dimensions and overarching characteristics. Elements consist of a policy strategy with long-term targets and principal plans, and an instrument mix with interacting policy instruments, including the instruments' type and design features. Processes comprise policy making and implementation. These processes shape the policy mix elements and might also have a direct effect on the performance of the policy mix, e.g. through signals they send out. Characteristics describe the nature of the policy mix and include policy mix consistency, coherence of policy processes, credibility, stability and comprehensiveness. For instance, credibility - as a potentially highly influential characteristic - means the extent to which the policy mix is believable at a general level and at the level of particular elements or processes. Finally, dimensions serve to specify elements, processes and characteristics, and thus the scope of a policy mix. They comprise, among others, the governance level, such as regional versus national, actors including both policy and target actors, and time, which captures the dynamic nature of policy mixes.

\subsection{Analytical framework}

In this study we take a first step incorporating the policy mix concept proposed by Rogge and Reichardt (2013) into the TIS framework by explicitly including the policy mix as one of the constituents of the structural component of 'institutions' in TIS. As the structure of the TIS for a large part determines its functioning, we can zoom in on the impact of the policy mix on TIS functioning. This implies that, on the one hand, the framework enables an analysis of the role of the policy mix with its policy strategy, the instrument mix, the processes of policy making and implementation and policy mix characteristics, for TIS functioning. On the other hand, the framework allows for studying the influence of certain TIS developments, e.g. functions and systemic problems, on the development of these policy mix components. Thereby, changes in the policy mix require interaction between policy makers and other TIS actors, i.e. politics are at play. Although we will not elaborately study such politics, we acknowledge that without these the policy mix would not change. We will therefore name relevant organizations and their roles in the context of particular problems in the TIS.

\section{Offshore wind in Germany}

Offshore wind is to play a considerable role in the German energy transition, 'Energiewende' (BMWi and BMU, 2010), in which the country aims to transform its energy sector towards more renewable energy

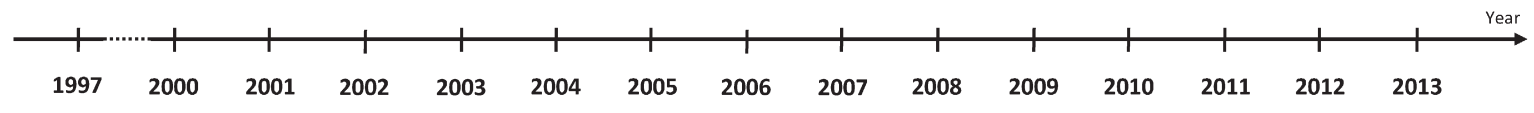

方岕

$\underline{01 / 2002}$
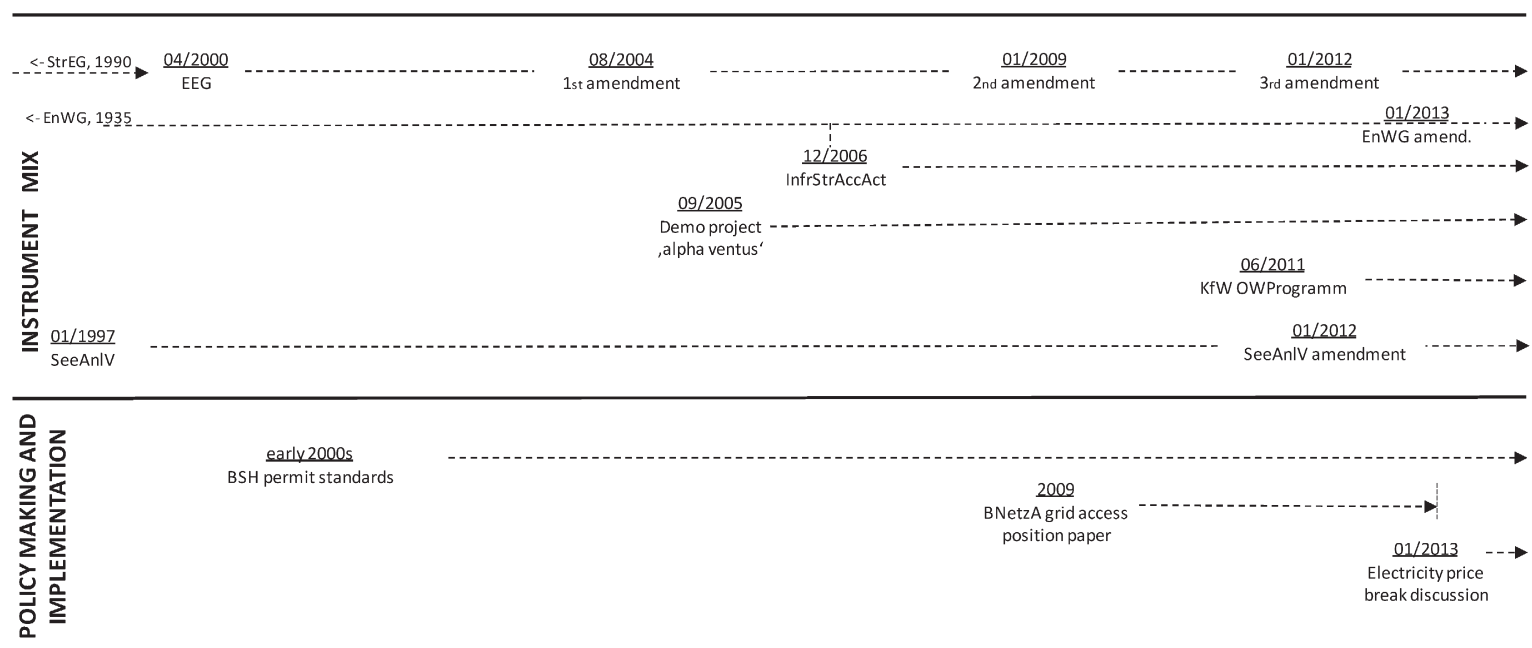

Fig. 1. Evolution of key elements and processes of the German offshore wind policy mix. 
Table 3

Overview of expert interviews.

\begin{tabular}{|c|c|c|c|c|}
\hline Actor type $^{1}$ & Actor name & \# Interviews & Interview duration & Interview date \\
\hline \multirow[t]{5}{*}{ Government } & Federal Ministry for Environment (BMU) & 2 & $117 \mathrm{~min}$ & $07 / 08 / 13$ \\
\hline & & & $87 \mathrm{~min}$ & $15 / 01 / 14$ \\
\hline & Federal Maritime and Hydrographic Agency (BSH) & 2 & $99 \mathrm{~min}$ & $08 / 08 / 13$ \\
\hline & & & $112 \mathrm{~min}$ & $07 / 11 / 13$ \\
\hline & Federal Network Agency (BNetzA) & 1 & $50 \mathrm{~min}$ & $13 / 01 / 14$ \\
\hline \multirow{3}{*}{ Companies } & German manufacturer of OW turbines & 1 & $86 \mathrm{~min}$ & $08 / 02 / 13$ \\
\hline & German operator of OW farm & 1 & $85 \mathrm{~min}$ & $19 / 02 / 13$ \\
\hline & Tennet (grid operator) & 1 & $100 \mathrm{~min}$ & $13 / 11 / 13$ \\
\hline \multirow[t]{2}{*}{ Financial organization } & Reconstruction Loan Corporation (KfW) & 2 & $30 \mathrm{~min}$ & $28 / 11 / 13$ \\
\hline & & & $58 \mathrm{~min}$ & $04 / 12 / 13$ \\
\hline Knowledge institute & Center for Wind Energy Research (ForWind) & 1 & $40 \mathrm{~min}$ & $27 / 11 / 13$ \\
\hline \multirow[t]{4}{*}{ Industry organization } & Stiftung Offshore Windenergie & 1 & $200 \mathrm{~min}$ & $31 / 07 / 13$ \\
\hline & Wind Energy Agency (wab) & 1 & $78 \mathrm{~min}$ & $26 / 07 / 13$ \\
\hline & German Engineering Association (VDMA) & 2 & $102 \mathrm{~min}$ & $17 / 10 / 13$ \\
\hline & & & $31 \mathrm{~min}$ & $18 / 12 / 13$ \\
\hline NGO & World Wide Fund for Nature (WWF) & 1 & $90 \mathrm{~min}$ & $09 / 08 / 13$ \\
\hline SUM & & 16 & $1365 \min (22.75 \mathrm{~h})$ & \\
\hline
\end{tabular}

1 Based on Wieczorek and Hekkert (2012)

technologies. In the context of this transition, by 2020 a share of $35 \%$ of power consumption is envisaged to come from renewable energy technologies, which is to rise to more than $80 \%$ by 2050 . Against this background, ambitious long-term capacity targets for offshore wind were established already in 2002, namely $10 \mathrm{GW}$ by 2020 and $25 \mathrm{GW}$ by 2030 . These targets were adjusted downwards - to become more 'realistic' - to $6.5 \mathrm{GW}$ and $15 \mathrm{GW}$, respectively, by the new government in 2013 (CDU et al., 2013, see Table 2). They nonetheless concede a significant role to offshore wind, which is also visible in the rich policy mix that has emerged over the past 20 years and that continues to incentivize investments into the technology (see Fig. 1).

The significance of the technology is mainly due to its large technological potential. Energy yields offshore are higher and steadier, reaching up to 4000 full-load hours per year compared to 2000-2500 full-load hours onshore (EWEA, 2009). The limited spatial potential for onshore growth in Europe adds to the great growth prospects of offshore wind not just in Germany but across the EU (Praessler and Schaechtele, 2012). Thus, $40 \mathrm{GW}$ capacity is estimated to be installed in EU countries by 2020 (EWEA, 2011b).

Despite its potential, the technology is confronted with difficulties. One is that offshore wind faces more challenging conditions than its onshore counterpart (IEA, 2009). For example, the marine environment with its salt water and higher wind speeds intensifies corrosion and puts higher demands on turbine materials. A particularity in Germany is the relatively long distance that offshore wind parks are located from the coast (usually at least $40 \mathrm{~km}$ ). This is due to the near-shore nature protection area Wadden Sea in the North Sea and anticipated public acceptance problems in near-shore waters in the Baltic Sea. These particularities are a major reason for the immaturity of the technology, which is reflected in relatively low capacities currently installed in the EU and Germany compared to their ambitious 2020 targets (Table 2, EWEA, 2011a,b). Relatedly, offshore wind costs are still comparatively high, ranging between 12.8 and $14.2 \mathrm{ct} / \mathrm{kWh}$ in Germany (Fichtner and Prognos, 2013). However, costs are expected to fall to $9 \mathrm{ct} / \mathrm{kWh}$ by 2020.

\section{Method}

In order to answer our research question of how the German offshore wind TIS and its corresponding policy mix evolve and influence each other, we combine event history analysis with interviews. While the event history analysis provides an overview of the evolution of the offshore wind TIS and its policy mix, i.e. of what happens, interviews create deeper insights in the interdependencies between the policy mix and the TIS. They reveal why and how the TIS and its policy mix came into being and how they influenced each others' development, thereby also shedding light on the effects of the policy mix on the TIS.

We proceeded in two main steps. First, by applying event history analysis we reconstructed the development of the German offshore wind TIS. In doing so we selected all articles on offshore wind in Germany between 1993 and 2013 from the European magazine Wind Power Monthly and extracted all relevant events ${ }^{1}$ (Negro et al., 2007). We chronologically put these events in a database allocating each event to one of the seven TIS functions, according to functions indicators established in the literature (Negro et al., 2007). Besides this, for getting insights into the evolution of policy mix components we screened related policy documents. These documents and the events constitute the basis - providing the facts - for our analysis of the evolution of the TIS and its policy mix. For clearly pointing out the policy mix terminology in the description of the TIS evolution, we indicate the policy mix components in squared brackets in Section 5 (see the table in the annex for an overview of policy mix components and their abbreviations). Also, based on the TIS events we analyzed the system functions over time (indicated in brackets in Section 5) and identified major systemic problems. We described the TIS development in five time periods. The end of each period was chosen on the basis of change in activities or key events, which is why not all periods are equal in length (Negro et al., 2007).

Second, between February 2013 and January 2014 we conducted 16 expert interviews to gain deeper insights into the role of policy mix components for TIS functioning and performance. We also explored why and in which way the policy mix elements were put in place in relation to TIS development. For obtaining detailed information on these issues, we selected long-standing experts in the field representing all main stakeholder groups in the TIS (see Table 3). In order to safeguard the interviewees' and their associations' anonymity, in Section 5 we randomly allocated each interviewee to a letter from A to P. We transcribed and coded all 16 interviews, which were conducted by telephone and in total added up to almost 23 hours, using the qualitative data analysis software Atlas.ti. Our code list comprised codes for systemic problems in the TIS and for the policy mix components (policy strategy, policy instruments, policy mix characteristics, policy processes) that were put in place, often to address these systemic problems. In our analysis we combined interview data with the information gathered in the event history analysis, and triangulated our findings with secondary data from publicly available reports and databases on offshore wind in Germany. Together, this allowed for a rich description of the interdependencies of the TIS and its policy mix.

\footnotetext{
${ }^{1}$ An event can be defined as 'the smallest meaningful unit in which change can be detected' (Poole et al., 2000).
} 


\section{Development of the German offshore wind TIS and its policy mix from 1993 to 2013}

In the following we describe the evolution of the German offshore wind TIS and its policy mix over the past 20 years, dividing this period in five phases.

\section{Phase 1. Pioneers' era (1993-1999).}

In 1993, one of the first wind conferences 'Husum Wind Energy Days' takes place in Husum, where a report is presented by British consultants Garrad Hassan and German classification society Germanischer Lloyd, revealing the enormous potential of offshore wind (F3; F4) (Wind Power Monthly, 1996). The interest in offshore wind in Germany continues to grow due to the positive developments of this technology in pioneer countries such as Denmark (Interviewee A) and the rapid growth of German onshore wind (F4). As early as in 1994, first plans for offshore parks are made by small planning firms, e.g. in the Baltic Sea off the Rostock coast (F1) (Wind Power Monthly, 1994). The most important policy instrument incentivizing advancements in the (onshore) wind technology at that time is the Electricity Feed-in Law (EFL, predecessor of the EEG) from 1990, a demand-pull instrument granting fixed-premium payments for electricity from wind and other renewable energy technologies [In.dp]. Offshore wind pioneers believe that such a premium payment would eventually also be put in place for offshore wind (Interviewee E), which contributes to driving their activities (F4).

In the late 1990s, a lot of technology development occurs (F2). For instance, German-Danish wind turbine maker Nordex develops a 2.5 MW offshore turbine (Wind Power Monthly, 1999). Furthermore, many requests for projecting offshore wind farms are posed - mainly by small onshore wind planning firms such as Plambeck and PROKON Nord (Interviewee E) - including a 16 turbine project close to the huge German port of Wilhelmshaven planned by Winkra-Energie (Wind Power Monthly, 1998). It is these small, innovative technology providers of onshore wind turbines and onshore wind project developers that initiate and significantly push the development of the offshore wind technology in Germany.

Despite quite some activities in the technology, so far there is no comprehensive policy mix in place for offshore wind [PM.compr]. One example is the lack of regulation for handling offshore wind permission requests. As a response to first such requests by wind planning firms, in January 1997 the responsible transport ministry (BMVBS) sets up the Marine Facilities Ordinance (SeeAnlV) [P.impl; In.sys]. The ordinance requires that a wind farm project be approved provided that it does not impair the safety and efficiency of navigation, and is not detrimental to the marine environment (F4) (BSH, 2014, Interviewee E). However, the agency carrying out the application procedure of offshore wind farm projects in the Exclusive Economic Zone (EEZ) ${ }^{2}$ of the German North Sea and Baltic Sea, the Federal Maritime and Hydrographic Agency (BSH), cannot hark back to any rules to apply when handling permission requests. For dealing with requests in the early 2000s, within the frame of the SeeAnlV the BSH thus autonomously sets up procedures from scratch [P.impl], and is thereby struggling to attract enough manpower to process all requests $(-\mathrm{F} 6)$ (Wind Power Monthly, 2001a, Interviewee E).

In sum this first phase is characterized by a lot of optimism and high expectations of pioneers and entrepreneurs (F4). Things are still relatively chaotic but at the same time also very dynamic, "with a very optimistic and cooperative feel to it" (Interviewee E). There are various plans for wind parks and many technology development activities (F2). Because this is an emerging technology, a comprehensive policy mix including a standardized permit process has not yet been established

\footnotetext{
2 Most of the German offshore wind farms are planned to be installed in the EEZ. Within the 12 nautical mile limit, i.e. the area of the territorial sea, responsibility for approval of wind farms rests with the German coastal states (BSH, 2014).
}

[PM.compr] ( $-\mathrm{F} 4)$. The lack of a permit process is, however, addressed by the authority in charge by establishing standards for handling offshore wind permit applications (F4).

Phase 2. Early growth (2000-2004).

In April 2000, for further fostering renewable energy technologies the newly elected red-green coalition introduces the Renewable Energy Act (EEG) [P.mak; In.dp] (F5), which replaces and extends the EFL (IEA, 2013). Transmission system operators are obliged to buy all wind kilowatt hours generated by renewable energy technologies, including wind, at a technology-specific fixed minimum price. They can spread the cost of their purchases equally across all consumers. This guaranteed technology-specific feed-in tariff (FIT) for wind power (to this point just one tariff for onshore and offshore wind) and the Sea Plant Ordinance are at that time the only policy instruments in place for offshore wind [In]. Particularly the EEG and actors' expectations of a sufficiently high FIT for offshore wind [PM.cred] trigger planning-firms' activities in the technology as well as technology development (F1; F2; F4) (Interviewee E).

In 2001, the BSH grants the first permit to the project Borkum West 1 [P.impl] (later renamed to become the demonstration project Alpha Ventus) commissioned by the planning-company PROKON Nord (F4) (Wind Power Monthly, 2001b). Further project approvals follow, such as in 2002 for the 240 MW Butendiek project (Wind Power Monthly, 2003a,b).

Progress is also made with the offshore wind port infrastructure. For instance, based on a study by Olav Hohmeyer (professor of energy and resources at Flensburg University) forecasting a bright future development of offshore wind in Germany (Wind Power Monthly, 2003c), the federal state of Schleswig-Holstein grants 13 million Euros for an expansion of Husum port [In.sys] (F6), with half of the sum to be provided by the EU (F4) (Wind Power Monthly, 2003c). In addition to these infrastructure advancements, German turbine developers including Repower and Enercon drive knowledge creation by developing the first big German offshore turbines. Repower builds its $5 \mathrm{MW}$ prototype in the Elbe river estuary as early as in December 2004, and at around the same time Enercon builds its E112 near-shore prototype in the Emden port (F2).

Offshore wind development enjoys remarkable cross-party political support, particularly from north German state governments that hope to enliven industrial activity and employment in the economically weak coastal regions (F4; F7) (Wind Power Monthly, 2003a). With the goal to further and more significantly advance offshore wind, in 2002 two policy makers in the Federal Environment Ministry (BMU) proactively develop a long-term action strategy for the technology the offshore wind strategy [PS] (F4) (Bundesregierung, 2002, Interviewee $\mathrm{B}$ ). Since this strategy is endorsed by the environment minister who brings it into the cabinet, it is officially adopted by the German government [P.mak]. It foresees to have installed $10 \mathrm{GW}$ of offshore wind capacity by 2020 and 25 GW by 2030 . Although it is not legally binding, the strategy creates big expectations regarding the further development of the technology, thus spurring innovative activities in the short and long term (F4).

However, large electricity utilities such as E.ON and RWE generally oppose the young offshore wind technology ( $-\mathrm{F} 7)$. They are mainly complaining about the extra cost of balancing supply and demand that they claim are inflicted on the system by such an intermittent energy source. Additional opposition comes from German environmental groups, such as Naturschutzbund (Nabu) and Bund für Umwelt und Naturschutz Deutschland (BUND) (-F7). In 2003, they launch legal procedures to stop development of the permitted offshore wind farm Butendiek in the North Sea because the project lies in a nature protection area. Also, they plan to extend their legal campaign to other offshore projects (Wind Power Monthly, 2003d).

In 2004 an amendment of the EEG comes into force [In.dp], based on an experience report that the German government regularly has to 
conduct (F4). Rooted in the insight that offshore wind is technologically different from onshore wind and that it features higher costs, the wind FIT is split into offshore and onshore, with the offshore tariff amounting to $9.1 \mathrm{ct} / \mathrm{kWh}$ for twelve years (and thus being higher than the onshore tariff, F5). Also, mainly due to the increasing opposition of environmental groups against offshore wind projects, a clause is included in the EEG excluding farms in nature protection areas from feed-in-tariffs (Interviewees $\mathrm{D}, \mathrm{L}$ ). This leads to greater acceptance of offshore wind also by nature conservationists (F7).

Summing up, in this second period the national and regional governments play a more active role. They support offshore wind with longterm guidance in the form of the offshore wind strategy and an amendment of the FIT, as well as large investment in the creation of an offshore wind industry in northern Germany (F4; F5). However, incumbent fossil fuel firms are reluctant to invest in offshore wind, and also environmental organizations protest against the location of offshore wind parks in nature protection areas $(-\mathrm{F} 7)$.

\section{Phase 3. Temporary Depression (2005-2006).}

This period is characterized by problems with cable connections of parks, which seriously hamper offshore wind projects ( $-F 1$ ) (Wind Power Monthly, 2005). According to the existing grid regulation anchored in the EEG [In.sys], project planners have to plan and finance their own cable, resulting in chaotic cable planning (Interviewees A; $\mathrm{J})$. Furthermore, long policy implementation procedures from the side of some federal states cause permit delays [P.impl]. These are due to, among others, nature protection conflicts when crossing the Wadden Zea (Interviewee L). Besides being ecologically detrimental, this adds to the economic non-attractiveness of offshore projects, for which the 2004 FIT has been identified as too low in the light of rising costs [In.dp] ( - F5; - F6) (Interviewees A; J; M). Therefore, projects do not get going - despite many new construction permits issued by the BSH - putting the whole sector in a "somewhat depressive phase" (Interviewee $\mathrm{E}$ ).

Since the cable connection problems for offshore wind projects - uncoordinated planning and high costs - have become so severe, affected actors such as project developers and the federal states call for a more centralized and coordinated cable planning, ideally done by the transmission system operator (TSO) and no longer by the park planners themselves. The BMU, being responsible for offshore wind ${ }^{3}$, finally becomes active and shifts the responsibility of providing grid connections for offshore wind farms to the TSOs (F4) (Interviewee A). These changes in offshore wind grid access regulation are then implemented in the Infrastructure Planning Acceleration Act (InfrStrAccAct) at the end of 2006, which amends the Energy Economy Law ${ }^{4}$ (EnWG) [P.mak; In.sys]. Creating positive expectations, they temporarily ease the cable connection situation.

Summing up, the main barriers in this period are delayed permits of cable connections of parks and chaotic cable planning of offshore wind projects due to inappropriate existing regulation [In.sys], which makes technology use economically unattractive $(-\mathrm{F} 4 ;-\mathrm{F} 6)$. These problems are articulated by several organizations in the offshore wind TIS. The government responds to these problems and improves the organization of the cable planning [P.mak; In.sys] in order to reduce delays and costs for the park operators. By removing these barriers, activities can be continued and a growth of the German offshore wind TIS is expected.

Phase 4. Birth of test field Alpha Ventus and rapid growth (2005-2009).

\footnotetext{
3 The Federal Ministry of Economic Affairs (BMWi) is actually responsible for grids, including those for offshore wind. However, due to its opposition against offshore wind the BMU often takes action in its place.

${ }^{4}$ The EnWG originally regulated fundamental aspects of grid-bound electricity supply, such as approval obligations, grid operation and utilities' obligation to contract with consumers.
}

In parallel to the negative events in the previous period, also significant positive developments begin to take place in the German offshore wind TIS. Industry representatives had called for an offshore wind workshop during the biannual national maritime conference in 2005. In this workshop, it is predominantly turbine manufacturers that demand establishing a test field, since offshore wind projects have still not taken off. In subsequent discussions between such technology firms and the environment ministry BMU on how to realize such a test field, the BMU suggests creating a foundation, the "Foundation Offshore Wind Energy", for further developing this project. A broad range of actors involved in offshore wind joins this foundation, which is mainly financed by the BMU. Also the BMU asks the initiators of the test field, turbine manufacturers, to participate in the project. Repower, Multibrid (now AREVA) and Enercon join to provide four turbines each that they fund by themselves (Interviewee J). However, Enercon soon drops out and completely quits offshore wind, presumably due to technical problems and resentment against the technology by the company head Alois Wobben (Interviewee A). Repower and Multibrid are invited to fill the gap by delivering two extra turbines, i.e. six instead of four turbines, each, but they object operating them. Therefore, the Offshore Wind Foundation asks the three utilities EWE, E.ON and Vattenfall that - as responsible grid operators for the German North and Baltic Sea - originally only were to provide the grid access for Alpha Ventus within the operator consortium DOTI ("Deutsche Offshore-Testfeld und Infrastruktur GmbH") (Interviewee A). The three firms are willing to also operate the test farm. In this whole process the Offshore Wind Foundation plays a key role as moderator, e.g. convincing both the turbine manufacturers and utilities to participate in Alpha Ventus. In addition, the demonstration project profits from the backing of the responsible BMU. This backing well exceeds a 50 million Euros grant for a number of research projects accompanying Alpha Ventus [In.tp] (F6). It also comprises a general positive attitude and constant support for offshore wind (F4) (Interviewees A; E; J).

Despite all the Alpha Ventus preparatory activities, by the end of 2008 no offshore wind capacity is online yet. One major reason for this is the - due to rising costs - underestimated level of the 2004 FIT. In 2007, the discussion on raising the offshore wind FIT is fuelled by the mandatory EEG experience report, the basis of which form scientific studies by independent research institutes. A KPMG study from December 2007, commissioned by several firms, also points out the need for a higher FIT (F7). Thus in 2007 the grand coalition government proposes to increase the initial FIT from currently $9.1 \mathrm{ct} / \mathrm{kWh}$ to $11-$ $15 \mathrm{ct} / \mathrm{kWh}$, thereby creating positive expectations and first commercial interests in German offshore wind by large utilities such as EnBW (F1; F4; F5). Following several discussions, the 2009 EEG amendment comprises a rise of the offshore wind FIT to $13 \mathrm{ct} / \mathrm{kWh}$ for the first twelve years ${ }^{5}$, with a 'sprinter bonus' of $2 \mathrm{ct} / \mathrm{kWh}$ on top for projects that come online before 2016 [P.mak; In.dp] (EEG, 2009, Interviewee B).

Meanwhile the planning of the test field Alpha Ventus by the operator consortium DOTI continues. Due to approval problems for the big utilities E.ON and Vattenfall, the medium-sized utility EWE takes over the majority (almost 50\%) of the project, thus becoming its main driver. Despite some delays mainly because of logistical challenges (Interviewees B; E), after around four years of planning the $60 \mathrm{MW}$ farm starts operation in 2009 and is thus the first operational German offshore wind farm (F1; F2; F3) (Wind Power Monthly, 2010). A lot of (joint) learning has taken place during this planning-process, which the involved firms can later use for their commercial projects. The following successful operation of Alpha Ventus does not only demonstrate the feasibility of such large-scale deep-water projects with their great unknowns and risks but also send positive signals to other entrepreneurs and investors (F4) (Interviewees B; J; M).

These improvements - going operational of Alpha Ventus and the higher FIT of 2009 - lead to a big increase in trust and positive

\footnotetext{
${ }^{5}$ After this initial period the FIT is to fall to $3.5 \mathrm{ct} / \mathrm{kWh}$ for the remaining part of the 20 years in which it is granted.
} 
expectations in the German offshore wind sector, such as by large utilities (F4) (Wind Power Monthly, 2009a,b). Both events can be seen as tipping point in the German offshore wind TIS, initiating the actual take-off of many projects that have been bobbing up and down so far. From now on the sector grows substantially, i.e. new usually larger - firms enter the market, projects are being considerably advanced and actually constructed, and the responsible TSO TenneT builds the first cable connections for commercial farms (F1). It is only now - around 2008/2009 - that the big utilities enter the German offshore wind market. They do so in buying and realizing existing projects from small project developers that lack the (financial) resources to actually follow through these projects.

Overall, in this period policy makers - alerted by industry representatives - address the systemic problem of insufficient financial support instruments altering the corresponding policy instrument EEG [P.mak; In.dp] (F4; F5). Also the first test field for offshore wind starts operation. Consequently positive experiences and high expectations reinforce each other and trigger the growth of the German offshore wind TIS (F1; F4).

\section{Phase 5. Resource crisis (2009-2013).}

With more and more wind parks proceeding with their plans and taking investment decisions, some problems come more to the fore. First, regarding grid connections, the 2006 InfrStrAccAct had left open the conditions that offshore wind projects have to fulfill so that the TSO would actually start constructing a cable connection for the future farm. For deciding on this, TSO Tennet develops certain criteria. The finance commitment is one of these. However, the park planners cannot deliver it without having a grid connection. A problem of mutual dependence of the grid access and finance commitments arises, commonly referred to as the "chicken-egg-problem". Addressing this serious bottleneck, in 2009 the regulator in charge (Federal Network Agency, BNetzA) proactively clarifies the cable connection conditions in a position paper, suggesting a clear order in which planners and TSOs should deliver proofs or contracts [P.impl] (F4) (BNetzA, 2009). After the introduction of this nonbinding position paper, the situation at first eases (F6), so that the first wave of investment decisions for around three GW takes place (F1) (Interviewee A). However, due to a number of problems on the side of the responsible TSO TenneT, including technical difficulties such as with TenneT's suppliers (due to the novelty of the technology) and financial bottlenecks due to TenneT's relatively small size, the whole process of cable planning and implementation often takes much longer than anticipated - delays of more than a year are common. In most cases, the cable connection is not finished when the offshore wind farm is ready to start operation, thus causing high costs for the operators (Interviewees A; J; O; P).

In addition, in 2009-2010 the climax of the financial crisis is still going on when some of the first commercial projects need financing at the capital market. Due to the high uncertainties offshore projects feature, only about ten private banks grant loans of at most 30-50 million Euros for one project whose costs easily amount to 1.5 billion Euros. This means that the capital on the financial market does not suffice for these first projects ( - F6). Responding to this bottleneck, the government sets up a loan program in mid 2011 [P.mak; In.sys], which is issued by the publicly owned Development Loan Corporation (KfW bank). This program grants loans at market conditions for up to ten offshore wind farms in Germany and as such potentially eases the tight financial situation $^{6}$ (F6). However, its main initial effect is probably the positive signals it sends out regarding the ongoing political will to support offshore wind (F4) (Interviewee K).

\footnotetext{
${ }^{6}$ However, probably due to severe grid access delays hindering many projects, only few projects actually are in need of (external) capital and make thus use of this program (in 2013 only three projects have used the program) (Interviewee A).
}

One of the key events in this phase is initiated by the TSO TenneT. With an open letter to the chancellor, in November 2011 TenneT turns to the government announcing that the firm cannot keep up with the pace of installation of transmission cables in the North Sea due to bottlenecks with its suppliers, shortage of materials and a lack of finance (-F6) (Wind Power Monthly, 2011). TenneT states that the current law regulating grid access (EnWG) should be changed towards a more overarching offshore wind grid planning (Wind Power Monthly, 2012a). So far, the EnWG stipulates that the TSO entirely finance the grid connection. Utility E.ON and other planners warn they will halt their investments if the TSOs do not speed up the construction of transmission cables (-F4) (Wind Power Monthly, 2012b).

The government addresses these resource constraints in the following ways. In a reaction to the grid problem, which has built up and worsened over several years, in December 2012 the EnWG is finally amended [P.mak; In.sys] based on an initiative by the BMWi (responsible for grids) and the BMU, and in close cooperation with affected stakeholders (F4; F6) (Interviewees A; J). It introduces a system change in grid access whose main novelty is that the TSO and the project developer negotiate a fixed date for an operation-ready grid connection, which becomes mandatory 30 months before the date's expiry (formerly the grid connection had to be ready when the farm was ready to operate). If the TSO then cannot adhere to this fixed date, a liability clause ensures that the farm operator is compensated financially for each day the farm stands idle and thus cannot feed in electricity. Also, this system change foresees more frequent appraisal of the grid access situation and adjustments in planning, thereby involving all relevant stakeholders (Stiftung Offshore Windenergie, 2012).

Furthermore, in a reaction to the acute financial resources problem and besides the KfW loan program, the German government follows the suggestions of the 2011 EEG experience report and once again increases the offshore wind FIT in the 2012 EEG amendment [P.mak; In.dp]. It introduces the option of a so-called compression model, in which the initial FIT is higher (19 ct/kWh) but is granted for a shorter period (eight instead of twelve years). Alternatively, offshore wind farm operators can still choose the basic initial tariff of $15 \mathrm{ct} / \mathrm{kWh}$ for twelve years (F4; F5) (EEG, 2012).

Both of these improvements in the instrument mix do not only signal the sustained political will with regard to advancing offshore wind in Germany and therefore create new hopes and expectations that the situation will finally improve [PM.cred] (F4). They also trigger new innovation activities by offshore wind firms, which are, however, very soon foiled.

In January 2013, the environment minister Peter Altmaier makes waves in the renewable energy sector and beyond when announcing plans for lowering soaring electricity costs for consumers - the socalled electricity price brake [P.mak] (Rheinische Post, 2013). These plans foresee cuts in FITs for renewable energy technologies, including for existing plants (Spiegel Online, 2013). Although many of Altmaier's proposals are dismissed later on, this mere discussion creates huge uncertainties among investors in offshore wind. Investors put ongoing projects on hold, such as EnBW the parks He Dreiht and Hohe See, which also has negative implications for technology suppliers $(-\mathrm{F} 4)$. This discussion therefore immediately cushions the recent new hope that the dissolving of the grid access problem and the even higher (initial) FIT in the compression model has brought about (Interviewee $\mathrm{O}$ ).

In sum, the problems of grid connections for parks and financial resources bottlenecks due to the financial crisis dominate this phase. These problems delay offshore wind projects and make external investors reluctant to invest in these $(-\mathrm{F} 4 ;-\mathrm{F} 6)$. Reactions by the respective policy makers result in new or altered policy instruments [P.mak; In] that - in spite of being tardy - successfully address these problems and signal the strong political will to continue to support the growth of the German offshore wind TIS [PM.cred] (F4). However, the electricity price brake discussion in early 2013 [P.mak], shortly after the former 
problems are solved, immediately suppresses the newly created hopes and puts many activities on hold (-F4).

\section{Discussion of dynamic policy mix-TIS interdependencies}

Having outlined the evolution of the offshore wind TIS and its policy mix, in the following we will shed more light on dynamic interdependencies in this evolution (see Table 4). We will thereby consider all major components of the policy mix concept, namely the policy strategy, the instrument mix, policy processes, policy mix characteristics and actors as an important dimension of the policy mix. The development of the German offshore wind TIS and its policy mix is tightly interlinked: early TIS developments, such as entrepreneurial activities, occur, requiring some kind of policy regulation. In reaction to these activities policy mix components are therefore introduced, which enable TIS developments to continue. However, problems emerge in the TIS, and policy mix components are subsequently adjusted to address these. Once these problems appear to be resolved, TIS developments continue, but then new or reinforced problems come up. There is again an adjustment of the policy mix, and so forth. These interdependencies are a continuous cycle in which the TIS constantly influences the policy mix and vice versa, so that both continue to develop and expand.

Two key patterns of these dynamic interdependencies are, first, that early entrepreneurial activities need regulation in the form of policy mix components. These newly set up policy mix components subsequently enable TIS development to continue, as in the case of the permit standards introduced by the Maritime and Hydrographic Agency. This is an example of policy implementation - since the standards were passed by a public authority - which responded to a lack of detailed rules on how to handle permission requests. Second, policy mix components are set up or adjusted to remedy severe problems in the TIS, which occur in relation to concrete planning activities starting in the early to mid 2000s. These policy mix components alleviate problems of the time, so that TIS developments can continue. This frequently occurring main pattern applies to a number of policy mix components introduced

Table 4

Changes in policy mix components, how they were influenced by the TIS and their main effects on TIS functions and performance.

\begin{tabular}{|c|c|c|c|c|c|c|c|}
\hline \multirow{2}{*}{$\begin{array}{l}\text { Policy mix } \\
\text { component }\end{array}$} & \multirow{2}{*}{$\begin{array}{l}\text { Type of } \\
\text { policy mix } \\
\text { component }^{*}\end{array}$} & \multirow{2}{*}{$\begin{array}{l}\text { Year of } \\
\text { introduction/ } \\
\text { alteration }\end{array}$} & \multirow{2}{*}{$\begin{array}{l}\text { Main involved } \\
\text { actors }\end{array}$} & \multicolumn{2}{|l|}{ TIS influence on PM components } & \multicolumn{2}{|l|}{ PM component influence on TIS } \\
\hline & & & & $\begin{array}{l}\text { Underlying TIS developments } \\
\text { for coming about of PM } \\
\text { components }\end{array}$ & $\begin{array}{l}\text { Involved } \\
\text { TIS } \\
\text { functions }\end{array}$ & $\begin{array}{l}\text { Effects of PM components on TIS } \\
\text { performance (technology development, } \\
\text { use, diffusion) }\end{array}$ & $\begin{array}{l}\text { Main effects } \\
\text { on TIS } \\
\text { functions }\end{array}$ \\
\hline SeeAnlV & In.sys & 1997 & $\begin{array}{l}\text { Entrepreneurs, } \\
\text { BMVBS }\end{array}$ & $\begin{array}{l}\text { No regulation in place for } \\
\text { handling offshore wind } \\
\text { permission requests }\end{array}$ & F1, F5 & $\begin{array}{l}\text { Enables OW }{ }^{\mathrm{a}} \text { permits } \rightarrow \text { potentially } \\
\text { contributes to technology use }\end{array}$ & $+\mathrm{F} 5$ \\
\hline Permit standards & P.impl & early 2000s & BSH & $\begin{array}{l}\text { No detailed rules for handling } \\
\text { permission requests }\end{array}$ & $\mathrm{F} 1, \mathrm{~F} 5$ & $\begin{array}{l}\text { Enables standardized permit process } \rightarrow \\
\text { potentially contributes to technology use }\end{array}$ & +F5 \\
\hline EEG introduction & In.dp & 2000 & $\begin{array}{l}\text { Red-green } \\
\text { government }\end{array}$ & $\begin{array}{l}\text { First time greens in government } \\
\rightarrow \text { green party support }\end{array}$ & F4 & $\begin{array}{l}\text { Investment trigger and guidance } \rightarrow \\
\text { potentially drives technology use } \& \\
\text { diffusion }\end{array}$ & $+\mathrm{F} 4,+\mathrm{F} 5$ \\
\hline $\begin{array}{l}\text { Offshore wind } \\
\text { long-term } \\
\text { target }\end{array}$ & PS & 2002 & $\begin{array}{l}\text { Two policy makers } \\
\text { from BMU }\end{array}$ & $\begin{array}{l}\text { Early entrepreneurial activities } \rightarrow \\
\text { wish to provide guidance and thus } \\
\text { push TIS development }\end{array}$ & F4 & $\begin{array}{l}\text { Stimulates subsequent innovation } \\
\text { activities } \rightarrow \text { contributes to higher } \\
\text { technology development activities, later } \\
\text { to technology use \& diffusion }\end{array}$ & $\begin{array}{l}+\mathrm{F} 2,+\mathrm{F} 4 \\
+\mathrm{F} 5\end{array}$ \\
\hline $\begin{array}{l}\text { EEG amendment: } \\
\text { OW FIT } \\
\text { introduction }\end{array}$ & In.dp & 2004 & $\begin{array}{l}\text { Scientists, BMU, } \\
\text { environmental } \\
\text { NGOs }\end{array}$ & $\begin{array}{l}\text { EEG experience report: offshore } \\
\text { more expensive than onshore } \\
\text { wind }\end{array}$ & F5 & $\begin{array}{l}\text { No more FIT for parks in nature } \\
\text { protection areas } \rightarrow \text { reduced opposition } \\
\text { by environmental NGOs }\end{array}$ & $+\mathrm{F} 7$ \\
\hline InfrStrAccAct & In.sys & 2006 & $\begin{array}{l}\text { BMU, BMWi, farm } \\
\text { planners }\end{array}$ & $\begin{array}{l}\text { Uncoordinated cable planning, } \\
\text { ecological and economic } \\
\text { non-effectiveness }\end{array}$ & F5, F6 & $\begin{array}{l}\text { Cable connection problems ease } \rightarrow \\
\text { accelerates potential technology use and } \\
\text { diffusion }\end{array}$ & $+\mathrm{F} 5$ \\
\hline $\begin{array}{l}\text { Setting up } \\
\text { demonstration } \\
\text { project Alpha } \\
\text { Ventus }\end{array}$ & In.tp, In.dp & $\begin{array}{l}\text { planning } \\
\text { start: } 2005\end{array}$ & $\begin{array}{l}\text { TPs, OW } \\
\text { Foundation, BMU }\end{array}$ & $\begin{array}{l}\text { Offshore wind does not take off } \\
\text { partly due to technical } \\
\text { uncertainties }\end{array}$ & $\mathrm{F} 1, \mathrm{~F} 2$ & $\begin{array}{l}\text { Demonstrates feasibility of offshore wind } \\
\text { and increases credibility \& expectations: } \\
\text { big utilities enter offshore wind, projects } \\
\text { take off } \rightarrow \text { stimulates technology use and } \\
\text { diffusion }\end{array}$ & $\begin{array}{l}+\mathrm{F} 1,+\mathrm{F} 2 \\
+\mathrm{F} 3,+\mathrm{F} 4 \\
+\mathrm{F} 5,+\mathrm{F} 7\end{array}$ \\
\hline EEG amendment & In.dp & 2009 & $\begin{array}{l}\text { Farm planners, } \\
\text { industry } \\
\text { associations, } \\
\text { scientists, BMU }\end{array}$ & $\begin{array}{l}\text { Offshore wind does not take off } \\
\text { partly due to low FIT (relative to } \\
\text { higher than expected costs) }\end{array}$ & F1, F5 & $\begin{array}{l}\text { Makes OW projects economically } \\
\text { attractive: big utilities enter OW \& } \\
\text { projects take off } \rightarrow \text { stimulates technology } \\
\text { use and diffusion }\end{array}$ & $\begin{array}{l}+\mathrm{F} 1,+\mathrm{F} 5 \\
+\mathrm{F} 6\end{array}$ \\
\hline $\begin{array}{l}\text { BNetzA position } \\
\text { paper }\end{array}$ & P.impl & 2009 & BNetzA, TSOs & $\begin{array}{l}\text { Chicken-egg-problem in grid } \\
\text { access } \rightarrow \text { timelines of cable and } \\
\text { farm planning are not compatible }\end{array}$ & $\mathrm{F} 1, \mathrm{~F} 4$ & $\begin{array}{l}\text { Cable connection problems ease } \rightarrow \text { first } \\
\text { wave of investment decisions taken } \rightarrow \\
\text { facilitates technology use \& diffusion }\end{array}$ & $\begin{array}{l}+\mathrm{F} 1,+\mathrm{F} 5 \\
+\mathrm{F} 6\end{array}$ \\
\hline $\begin{array}{l}\text { KfW offshore } \\
\text { wind program }\end{array}$ & In.sys & 2011 & BMU, KfW & $\begin{array}{l}\text { Lack of capital at financial market } \\
\text { during financial crisis }\end{array}$ & $\mathrm{F} 1, \mathrm{~F} 6$ & $\begin{array}{l}\text { Signal of persisting political will to } \\
\text { support OW, enables start of few projects }\end{array}$ & $\begin{array}{l}+\mathrm{F} 1,+\mathrm{F} 4 \\
+\mathrm{F} 5,+\mathrm{F} 6\end{array}$ \\
\hline $\begin{array}{l}\text { EnWG } \\
\text { amendment }\end{array}$ & In.sys & 2012 & $\begin{array}{l}\text { Tennet, BMU, } \\
\text { BMWi, OW } \\
\text { Foundation, farm } \\
\text { planners }\end{array}$ & $\begin{array}{l}\text { Escalation of grid access problem: } \\
\text { TenneT announces inability to } \\
\text { connect further farms under } \\
\text { current circumstances }\end{array}$ & F6 & $\begin{array}{l}\text { Relief \& new hope, farm planners intend } \\
\text { to continue planning } \rightarrow \text { potentially } \\
\text { enables continuation of technology } \\
\text { diffusion }\end{array}$ & $\begin{array}{l}+\mathrm{F} 1,+\mathrm{F} 4 \\
+\mathrm{F} 5\end{array}$ \\
\hline EEG amendment & In.dp & 2012 & $\begin{array}{l}\text { Industry \& } \\
\text { researchers, BMU }\end{array}$ & $\begin{array}{l}\text { Greater financial stimulus needed } \\
\text { due to financial resources } \\
\text { problem and low number of } \\
\text { implemented projects so far }\end{array}$ & F1, F6 & $\begin{array}{l}\text { Potentially triggers more projects to be } \\
\text { built }\end{array}$ & $+\mathrm{F} 6$ \\
\hline $\begin{array}{l}\text { Electricity price } \\
\text { brake discussion }\end{array}$ & P.mak & 2013 & $\begin{array}{l}\text { Environment } \\
\text { minister }\end{array}$ & $\begin{array}{l}\text { Increasing costs of EEG for } \\
\text { consumers }\end{array}$ & F7 & $\begin{array}{l}\text { Immediately brings ongoing projects to } \\
\text { halt; stops, puts on ice or slows down } \\
\text { OW technology development and } \\
\text { diffusion activities }\end{array}$ & $\begin{array}{l}-\mathrm{F} 1,-\mathrm{F} 2 \\
-\mathrm{F} 4,-\mathrm{F} 7\end{array}$ \\
\hline
\end{tabular}

$*$ PS = policy strategy, In.dp = demand pull instrument, In.tp = technology push instrument, In.sys = systemic policy instrument, P.impl = policy implementation, P.mak = policy making; ${ }^{\mathrm{a}} \mathrm{OW}=$ offshore wind. 
in a later phase, including the EEG amendments, the KfW program and the EnWG amendment from 2012.

Regarding the second interdependency pattern, we find that most systemic problems are addressed through the alteration of (mal-functioning) policy instruments, particularly demand pull and systemic instruments. For problems with demand pull instruments, dominated by the EEG with its FIT, it is normally the function market formation (F5), which is not working properly, causing problems with entrepreneurial activities (F1). Once these demand-pull instruments have been adjusted, market formation (F5), entrepreneurial activities (F1) and also guidance of the search (F4) improve, though often only temporarily. Systemic instruments, particularly the grid access regulation specified in the EnWG, tend to be changed in reaction to problems with market formation (F5) or resource mobilization (F6), which together hamper entrepreneurial activities (F1). The new or altered systemic policy instruments then contribute to stimulating these functions (F1, F5) and improve the guidance of the search (F4), thus temporarily alleviating important systemic problems. What both of these interdependencies have in common is that first attempts of addressing the occurring systemic problems did not lead to a long-lasting solution, despite initial signs of problem alleviation. This is mainly a consequence of unexpected developments, such as instrument mix interactions.

Unlike in other emerging renewable energy TIS, particularly in other countries (e.g. Jacobsson, 2008; Negro et al., 2007), problems in the German offshore wind TIS have so far always been addressed, i.e. the policy mix has always been adjusted to deal with unforeseen or underestimated problems, and as a consequence the TIS developed further. Thus the question arises why barriers have continually been addressed or even overcome. A major reason for this appears to be the combination of high commitment to the technology by policy makers and industry advocacy coalitions. Thereby, the strong and stable commitment for offshore wind by the former actors translates into a high value of the policy mix characteristic credibility and is reflected in a generally strong guidance of the search (F4) (Wieczorek et al., 2013). A crucial determinant of this high credibility is the long-term target for offshore wind together with the implementation of supporting instruments underlining the political will to promote the technology. The existence of this ambitious and credible long-term target - the key policy strategy element of the offshore wind policy mix - has stimulated innovation activities over a long time, particularly knowledge development (F2) and, in contrast to other policy mix components, did not contribute to systemic problems but had a very positive influence on TIS functioning and performance. However, this high policy mix credibility can quickly be destroyed and then bring TIS developments to a hold. This can be illustrated by the electricity price brake discussion in 2013, which is part of a policy-making process. It caused huge uncertainties based on which projects were put on hold $(-\mathrm{F} 1)$ and technology development was slowed down (-F2), even without any changes in the instrument mix.

Turning to actors as both a dimension of the policy mix and a structural component of TIS, other TIS actors besides policy makers - primarily industry actors - have a share in the (successful) continuation of the TIS and policy mix developments. This also confirms former studies stressing the importance of actors in innovation systems (Erlinghagen and Markard, 2012; Markard and Truffer, 2008b). Over time, several important actors have brought the TIS forward. Innovative and risk-taking entrepreneurs were crucial in a very early TIS phase, while subsequently single policy makers together with industry representatives organized in the Offshore Wind Foundation as well as other industry associations advocated the TIS, contributing to the design and implementation of favorable policy mix components. Finally, the entering of large utilities into the TIS, i.e. of incumbents, turned a formerly opposing actor group into offshore wind proponents (F7). The same applies to the formerly relatively passive economics ministry, and both the ministry and incumbents contributed to the take off of the TIS at around 2009. What was also fundamental for this take off was the pilot and demonstration project Alpha Ventus - a special kind of policy instrument and unique project. This project, which was called for by early entrepreneurs, pushed by the manufacturing industry association VDMA and supported by policy makers in the BMU, affected almost all TIS functions positively. For example, projects were being started or finally took off, since Alpha Ventus demonstrated the feasibility of projects in deep waters far off the shore (F1), and new knowledge on how to build and operate parks was developed (F2) and exchanged (F3).

While the patterns of development of the policy mix and TIS can be expected to continue, the reduced ambition levels of the so far stable long-term offshore wind target suggest a somewhat reduced momentum, with consequences for the future development of the German offshore wind TIS. The recent lowering particularly of the 2030 target from formerly $25 \mathrm{GW}$ to $15 \mathrm{GW}$ decreases market expectations and thus reduces the attractiveness of the German offshore wind market (Hamburger Abendblatt, 2014). This may negatively impact several TIS functions, such as entrepreneurial activities, and TIS performance, such as the rate of technology diffusion. In addition, the national policy mix and TIS might become less important since industry players may expand the geographical range of their markets to growing offshore wind markets abroad. Given that several other countries start to voice their interest in offshore wind, export markets could indeed counter these German growth reductions. Yet local content requests, as can be increasingly observed in the UK (Kern et al., 2014), for instance, may hamper such a Europeanization of the TIS, which may become a future concern of policy makers.

In sum, despite only touching upon the plethora of interdependencies that exist between the policy mix and TIS developments, our analysis demonstrates that all components of the policy mix interact with TIS developments. These often tight interactions are complex and do not only exist between the policy mix and TIS developments but also within each of these. For example, a policy-making element (the electricity price brake discussion) affected a policy mix characteristic (credibility), which then negatively affected some TIS functions (e.g. F1, F2). Although at first sight it seems to be policy instruments that interact most with the TIS, especially in relation with systemic problems, the role other policy mix components such as the policy mix characteristic credibility play should not be underestimated.

\section{Conclusion}

In this paper we took a first step towards a more explicit and differentiated consideration of the role of policies in the development of technological innovation systems. For doing so, we applied a comprehensive policy mix concept in our analysis of the TIS of offshore wind in Germany, studying the dynamic interdependencies between the policy mix and the rest of the innovation system. We found tight interlinkages reflecting continuous interactions between observed problems in the TIS, the articulation of these problems and the subsequent alteration of the policy mix in place. In this cycle the policy mix did not only positively influence TIS developments but also contributed to the emergence of new or to the reinforcement of existing systemic problems. Alterations in the policy mix were then needed to solve these new problems. Thus, the systemic problems and their attempted solution in turn shaped the evolution of the policy mix with its many technology-specific and some generic elements. In our analysis of policy mix-TIS interdependencies we considered all components of the policy mix concept, and we found that all of them interacted with TIS developments. These rather tight and often complex interactions did not only occur between the policy mix and TIS but also within each of these.

Conceptually, our analytical framework should be seen as a first step incorporating a more comprehensive policy mix concept into the TIS 
approach. We show that such a more differentiated treatment of policies in TIS enables a better understanding of the role and effectiveness of policy mix elements, processes and characteristics - rather than only of single policy instruments - for TIS development and functioning. Furthermore, this differentiated policy treatment provides deeper insights into the tight interdependencies between the TIS and policy mix developments over time. Analyzing not only the one-way link of how policies affect the TIS but also the reverse link contributes to a better understanding of real dynamics occurring in TIS (see Hoppmann et al., in press). Thereby our study underlines the need to reconsider the under-conceptualization of policies within the TIS approach, in which policies - or the policy mix - are so far hidden as one constituent of the institutions of a TIS and are at the same time used as indicator for TIS functions, such as market formation. This does not reflect their key importance particularly for emerging TIS, and is detrimental to proper evaluations of their actual effectiveness.

Based on our findings we derive four key implications for policy makers aiming to advance emerging TIS in the environmental field more generally. First, the existence of a policy strategy with an ambitious and stable technology-specific long-term target promises to be highly beneficial for stimulating TIS developments due to the market expectations it creates. Second, demand-pull instruments with design features tailored to the emerging technology, such as a feed-in tariff with a sufficient level of support, play a central role for TIS development. In addition, systemic instruments are also of crucial importance, both as initial catalyst by supporting pilot projects and as backing for enabling technologies and infrastructures. Third, a credible political commitment towards the technology is of great importance for such an emerging TIS, since it potentially acts as a main driver for continuing TIS developments in times of systemic problems. Finally, from a dynamic TIS development perspective, due to constant changes in the TIS flexible adjustments of policy mix elements appear vital for maintaining continuity in TIS development. This calls for the establishment of policy processes striking the delicate balance between providing stability and allowing for needed adjustments.

This study is not free from limitations and thus calls for future research, for which we see three main avenues. While we investigated the interdependencies between several policy mix components and the TIS over time, future studies should focus in more detail on often neglected policy processes and their role in TIS, as this may reveal additional insights into TIS dynamics. In addition, since actors greatly shape the TIS and the policy mix, analyzing agency and politics in more depth would contribute to a better understanding of TIS development. Finally, the TIS approach may benefit from a conceptual disentangling of policies, or more precisely of the policy mix, from the structures and functions of technological innovation systems.

\section{Acknowledgments}

We gratefully acknowledge the support of parts of this study by the Research Directorate-General of the European Commission (RESPONSES, Grant Agreement number 244092 and APRAISE, number 283121), the German Ministry of Education and Research (GRETCHEN, support code 01LA1117A), the RCUK through the EPSRC funded Centre on Innovation and Energy Demand (grant no. EP/K011790/1) and the Academy of Finland (grant no. 293405). In addition, we are grateful for valuable research assistance by Sebastian Goll and by several students of Utrecht University's Natural Science and Innovation bachelor 2013.

Finally, this paper benefited from feedback received at the 2014 International Conference on Policy Mixes in Environmental and Conservation Policies in Leipzig, Germany, and at the 2014 International Sustainability Transitions Conference in Utrecht, the Netherlands.

\section{ANNEX}

Policy mix components considered in the analysis.

\begin{tabular}{lll}
\hline Type of component & Policy mix component & Acronym \\
\hline Policy strategy & Policy strategy & PS \\
Instrument mix & Policy instrument & In \\
Instrument type & Demand-pull instrument & In.dp \\
& Technology-push instrument & In.tp \\
& Systemic instrument & In.sys \\
Policy mix characteristics & Policy mix comprehensiveness & PM.compr \\
& Policy mix credibility & PM.cred \\
Policy processes & Policy implementation & P.impl \\
& Policy making & P.mak \\
\hline
\end{tabular}

\section{References}

Bergek, A., Jacobsson, S., Carlsson, B., Lindmark, S., Rickne, A., 2008. Analyzing the functional dynamics of technological innovation systems: a scheme of analysis. Res. Policy 37, 407-429.

BMWi, BMU, 2010. Energiekonzept für eine umweltschonende, zuverlässige und bezahlbare Energieversorgung. Germany.

BNetzA, 2009. Bundesnetzagentur klärt Anbindung von Offshore-Windparks (Pressemitteilung).

Braathen, N.A., 2007. Instrument mixes for environmental policy: how many stones should be used to kill a bird? Int. Rev. Environ. Resour. Econ. 185-235.

BSH, 2014. Genehmigung von Offshore-Windenergieparks [WWW Document]. http:// www.bsh.de/de/Meeresnutzung/Wirtschaft/Windparks/ (accessed 4.15.14).

Bundesregierung, 2002. Strategie der Bundesregierung zur Windenergienutzung auf See im Rahmen der Nachhaltigkeitsstrategie der Bundesregierung. Berlin.

CDU, CSU, SPD, 2013. Deutschlands Zukunft gestalten. Koalitionsvertrag zwischen CDU, CSU und SPD, Deutschland.

EEG, 2009. Erneuerbare Energien Gesetz.

EEG, 2012. Erneuerbare Energien Gesetz.

Erlinghagen, S., Markard, J., 2012. Smart grids and the transformation of the electricity sector: ICT firms as potential catalysts for sectoral change. Energ Policy 51, 895-906.

EWEA, 2009. The Economics of Wind Energy. Brussels.

EWEA, 2011a. Wind in our Sails. Brussels.

EWEA, 2011b. The European Offshore Wind Industry. Brussels.

EWEA, 2014. Offshore Wind [WWW Document]. http://www.ewea.org/policy-issues/ offshore/ (accessed 4.14.14).

Fichtner, Prognos, 2013. Kostensenkungspotenziale der Offshore-Windenergie in Deutschland.

Flanagan, K., Uyarra, E., Laranja, M., 2011. Reconceptualising the "policy mix" for innovation. Res. Policy 40, 702-713.

Foxon, T.J., Gross, R., Chase, A., Howes, J., Arnall, A., Anderson, D., 2005. UK innovation systems for new and renewable energy technologies: drivers, barriers and system failures. Energ Policy 33, 2123-2137.

Hamburger Abendblatt, 2014. Siemens fürchtet Auftragsloch bei Windkraft.

Hekkert, M.P., Suurs, R.A.A., Negro, S.O., Kuhlmann, S., Smits, R.E.H.M., 2007. Functions of innovation systems: a new approach for analysing technological change. Technol. Forecast. Soc. Chang. 74, 413-432.

Hoppmann, J., Huenteler, J., Girod, B., 2014. Compulsive Policy-making - The Evolution of the German Feed-in Tariff System for Solar Photovoltaic Power Res. Policy (in press).

IEA, 2009. Technology Roadmap Wind Energy. Paris.

IEA, 2013. Energy Policy Highlights.

Jacobsson, S., 2008. The emergence and troubled growth of a "biopower" innovation system in Sweden. Energ Policy 36, 1491-1508.

Jacobsson, S., Bergek, A., 2011. Innovation system analyses and sustainability transitions: contributions and suggestions for research. Environ. Innov. Soc. Transitions 1, 41-57.

Kemp, R., Pontoglio, S., 2011. The innovation effects of environmental policy instruments. Ecol. Econ. 72, 28-36.

Kern, F., Smith, A., Shaw, C., Raven, R., Verhees, B., 2014. From laggard to leader: explaining offshore wind developments in the UK. Energ Policy 69, 635-646.

Kivimaa, P., Virkamäki, V., 2013. Policy Mixes, Policy Interplay and Low Carbon Transitions: The Case of Passenger Transport in Finland. Helsinki.

Lehmann, P., 2010. Using a Policy Mix to Combat Climate Change - An Economic Evaluation of Policies in the German Electricity Sector. Martin-Luther-Universität, Halle-Wittenberg.

Markard, J., Truffer, B., 2008a. Technological innovation systems and the multi-level perspective: towards an integrated framework. Res. Policy 37, 596-615.

Markard, J., Truffer, B., 2008b. Actor-oriented analysis of innovation systems: exploring micro-meso level linkages in the case of stationary fuel cells. Tech. Anal. Strat. Manag. 20, 443-464.

Matthes, F., 2010. Der Instrumentenmix einer ambitionierten Klimapolitik im Spannungsfeld von Emissionshandel und anderen Instrumenten. Berlin.

McDowall, W., Ekins, P., Radošević, S., Zhang, L., 2013. The development of wind power in China, Europe and the USA: how have policies and innovation system activities coevolved? Tech. Anal. Strat. Manag. 25, 163-185.

Nauwelaers, C., Boekholt, P., Mostert, B., Cunningham, P., Guy, K., Hofer, R., Rammer, C., 2009. Policy Mixes for R\&D in Europe. 
Negro, S.O., Hekkert, M.P., Smits, R.E., 2007. Explaining the failure of the Dutch innovation system for biomass digestion-a functional analysis. Energ Policy 35, 925-938.

Negro, S.O., Suurs, R.A.A., Hekkert, M.P., 2008. The bumpy road of biomass gasification in the Netherlands: explaining the rise and fall of an emerging innovation system. Technol. Forecast. Soc. Chang. 75, 57-77.

Poole, M.S., Van de Ven, A.H., Dooley, K., Holmes, M., 2000. Organization Change and Innovation Processes: Theory and Methods for Research. Oxford University Press, Oxford.

Praessler, T., Schaechtele, J., 2012. Comparison of the financial attractiveness among prospective offshore wind parks in selected European countries. Energ Policy 45, 86-101.

Rheinische Post, 2013. Regierung plant Bremse für den Strompreis.

Rogge, K.S., Reichardt, K., 2013. Towards a more comprehensive policy mix conceptualization for environmental technological change: a literature synthesis (No. S 3/2013). Working Paper Sustainability and Innovation. Karlsruhe.

Spiegel Online, 2013. Altmaier und Rösler einigen sich bei Strompreisbremse. Spiege Online.

Stiftung Offshore Windenergie, 2012. Lösungsvorschläge für die Netzanbindung von Offshore-Windparks der AG Beschleunigung Offshore-Netzanbindung. Berlin.

Suurs, R.A.A., Hekkert, M.P., Kieboom, S., Smits, R.E.H.M., 2010. Understanding the formative stage of technological innovation system development: the case of natural gas as an automotive fuel. Energ Policy 38, 419-431.

Tigabu, A.D., Berkhout, F., van Beukering, P., 2013. The diffusion of a renewable energy technology and innovation system functioning: comparing bio-digestion in Kenya and Rwanda. Technol. Forecast. Soc. Chang.

Truffer, B., Markard, J., Binz, C., Jacobsson, S., 2012. Energy Innovation Systems: Structure of an Emerging Scholarly Field and its Future Research Directions.

Weber, K.M., Rohracher, H., 2012. Legitimizing research, technology and innovation policies for transformative change. Res. Policy 41, 1037-1047.

Wieczorek, A.J., Hekkert, M.P., 2012. Systemic instruments for systemic innovation problems: a framework for policy makers and innovation scholars. Sci. Public Policy 39 74-87.

Wieczorek, A.J., Negro, S.O., Harmsen, R., Heimeriks, G.J., Luo, L., Hekkert, M.P., 2013. A review of the European offshore wind innovation system. Renew. Sust. Energ. Rev. 26, 294-306.

Wind Power Monthly, 1994. Off the Rostock Coast.

Wind Power Monthly, 1996. Grandiose Plans at Sea.

Wind Power Monthly, 1998. Megawatt Turbines for Huge Port.

Wind Power Monthly, 1999. Two New Nordex Turbines on the Way.

Wind Power Monthly, 2001a. Goodbye Nuclear and Hello Wind.

Wind Power Monthly, 2001b. Germany Grants First Offshore Licence.

Wind Power Monthly, 2003a. Approvals but German Offshore Lags Behind - No Action Until 2004.

Wind Power Monthly, 2003b. Two Down and Thirty to Go - German Offshore Approval.

Wind Power Monthly, 2003c. German North Sea Ports Wooing Wind.
Wind Power Monthly, 2003d. Green Groups Block German offshore - Objections to Butendiek Site.

Wind Power Monthly, 2005. First Permit Granted for Full Cable Route - Long Process Finally Over.

Wind Power Monthly, 2009a. German Offshore Expectations Left at Sea - Another Year, Another Broken Plan.

Wind Power Monthly, 2009b. Offshore: Global Market Study - Analysis Forecasts Offshore Boom.

Wind Power Monthly, 2010. Germany Looks to the Future and With Heavy Offshore Investment.

Wind Power Monthly, 2011. Tennet Hit by "Shortage of Cash and Cables.

Wind Power Monthly, 2012a. Tennet Warns German Government Over Offshore Grid.

Wind Power Monthly, 2012b. E.On Fires German Offshore Grid Warning.

Kristin Reichardt is a Ph.D. student at the Innovation Studies Group at Utrecht University, the Netherlands. She is an economist by training and from 2009 until 2014 was employed as a researcher and project manager at the Energy Policy and Energy Markets Competence Center of the Fraunhofer Institute for Systems and Innovation Research ISI in Karlsruhe, Germany. She now works for a Swiss utility company.

Simona Negro is an assistant professor at the Copernicus Institute of Sustainable Development. Her research aims to identify activities and strategies performed by actors, such as entrepreneurs, incumbent players or policy makers, that contribute to the dynamics of innovation systems.

Karoline Rogge is a lecturer in the Energy Policy and Sustainability at SPRU - Science Policy Research Unit at the University of Sussex and Senior Researcher at the Fraunhofer Institute of Systems and Innovation Research. Her research focuses on the link between policy and innovation in the context of climate change and ranges from evaluating the innovation impact of single policy instruments, such as the EU emissions trading system, to analyzing the effects of comprehensive policy mixes for promoting the low carbon transition of the energy system. In doing so, she combines insights from environmental economics, innovation, transition and policy studies.

Marko Hekkert is a professor for the Dynamics of Innovation Systems and head of Innovation Studies at Utrecht University. He studies the dynamics of emerging technological fields. Most of his studies focus on technological fields that contribute to a more sustainable society like renewable energy technologies. Theoretically he aims to contribute to the innovation systems perspective by improving our knowledge on how emerging innovation systems develop and what type of micromechanisms (e.g., power, lobby, research, strategy, expectations, resources) determine the dynamics of innovation systems. 